\title{
Centre Formation and the European Commission: A Research Note
}

\author{
Jarle Trondal*
}

University of Agder and ARENA Centre for European Studies, University of Oslo, Norway

\begin{abstract}
The preceding decade has witnessed a boost in research on the European Commission (Commission). One central issue debated has been Commission centre formation, both what it entails, its sources, and potential implications. Centre formation in this literature entails the internal integration of government institutions, thus reinforcing intrainstitutional administrative hierarchies. Contemporary research, however, offers inconclusive results as regards the internal integration of the Commission administration. The main motivation for this research note is to show that seemingly inconclusive findings in contemporary Commission research might in fact be complementary. Contemporary literature reports that centre formation inside the Commission is primarily observed at the helm of the Commission hierarchy within the General Secretariat - however only marginally affecting everyday decision-making within Commission sub-units (primarily the policy DGs (ministries)). Competing observations of this kind might be considered complementary because competing behavioural logics tend to co-exist within the Commission administration, albeit embedded and layered within different organisational sub-units.
\end{abstract}

Keywords: European commission, governance, integration theory, organisation theory, political science, public administration.

\section{INTRODUCTION ${ }^{1}$}

The past decade has witnessed a boost in research on the European Commission (Commission). One central issue debated has been Commission centre formation, both what it entails, its sources, and potential implications. Centre formation in this literature entails the internal integration of government institutions, thus reinforcing intra-institutional administrative hierarchies. Contemporary research, however, offers inconclusive results as regards the internal integration of the Commission administration ${ }^{2}$. The main motivation for this research note is to show that seemingly inconclusive findings in contemporary Commission research might in fact be complementary. Contemporary literature reports that centre formation inside the Commission is primarily observed at the helm of the Commission hierarchy - within the

*Address correspondence to this author at the Department of Political Science and Management, PO BOX 422, 4604 Kristiansand , Norway; Tel: +4738141561; E-mail: jarle.trondal@uia.no

\footnotetext{
${ }^{1}$ This research note is based on my comments to the panel 'The European Commission in Question: an Administration of the Twenty-First Century?' EUSA twelfth Biennial International Conference, Boston, Massachusetts, March 3-5, 2011. The research is financially supported by "EUROTRANS - The Transformation and Sustainability of European Political Order" (The Norwegian Research Council). The author is grateful to comments from two anonymous referees and Carolyn Ban on a previous version of the manuscript.

${ }^{2}$ Although beyond the scope of this article, the vast and growing research literature on the Commission harbours several contradictory findings. One example is on the 'myth of nationality' where new data on informal networking among Commission officials partly challenges previous findings by suggesting that nationality may play a larger role than previously envisaged (Peterson 2011; Suvarierol 2007). One second example is on the claimed weakening of the Commission relative to other EU institutions, notably the Union Council and the European Parliament. New studies largely challenged the alleged weakened Commission (see Curting and Egeberg 2008; Kassim and Menon 2004). Finally, research on internal administrative reforms in the Commission (the socalled 'Kinnock reforms') are inconclusive as regards the extent to which these reforms profoundly reshapes the nuts and bolts of the Commission administration (e.g. Bauer 2009; Trondal 2012). This article thus merely directs attention to one, however essential, inconclusiveness in contemporary Commission research.
}

General Secretariat - however only marginally affecting everyday decision-making within Commission sub-units (primarily the policy DGs (ministries)). Competing observations of this kind might be considered complementary because competing behavioural logics tend to co-exist within the Commission administration, albeit embedded and layered within different organisational sub-units.

A vast literature on state building has demonstrated how the extortion of new executive centres tends to involve delicate balancing acts between creating action capacities for the standardisation and penetration of the territory and concerns for local autonomy (Rokkan 1999). More recently, studies have suggested that centre formation at international level may profoundly transform executive orders at the level below. Studies suggest that international bureaucracies profoundly influence world politics (Biermann and Siebenhüner 2009), affect power distributions across levels of government (Egeberg and Trondal 2009), and transform domestic democratic governance (Keohane et al., 2009). Nevertheless, existing research is inconclusive as regards the extent to which the Commission is profoundly integrated as an executive centre steered primarily by presidential command. The most recent financial crisis that hit Europe has substantiated not only an ambition for presidential steering on behalf of Commission President Barroso but also the de facto limitation of Commission steering vis-à-vis competing executive centres in the member-states.

The strengthening of executive powers is comprehensively documented within national governments - notably enhancing the role of Prime Ministers' and Presidential Offices (Poguntke and Webb 2005) - thus reasserting centres of executive government (Christensen and Lægreid 2007). Identifying the degree of internal integration of the central political executive of the EU - which is the Commission and not the Union Council (cf. Kreppel 2011) - is essential for understanding European political order. Contemporary litera- 
ture, however, offers inconclusive results in this regard. One strand of contemporary research suggests that the Commission has become increasingly presidentialised, characterised by centre formation inside the Commission as well as regards its relationships with outside actors - such as international organisations, EU agencies, domestic governments, etc. (Kassim 2006; 2009; Kassim and Peterson 2011; Trondal 2010). The history of the Commission also documents periods of presidentialisation. Best known, perhaps, is the legacy of the Delors Commission (1985-95), characterised by presidential steering and a relative disregard of administrative routines (Christiansen 2008: 63; Kassim 2006). A second strand of research, however, highlights that presidentialisation of the Commission merely supplements the inherent horizontal specialisation and 'siloisation' of Commission sub-units (e.g. Trondal 2012). The Commission thus features a particular combination of two generic logics: a logic of hierarchy and a logic of portfolio.

The key purpose of this review essay is less to provide a complete empirical picture of contemporary Commission research, but also highlight how seemingly inconclusive findings may be reconciled. In doing so, there is a deliberate bias in this research note article towards recent literature. The research note is sequenced as follows: The next section outlines centre formation as an analytical concept. If centre formation is happening within the Commission, how can we recognise it? The subsequent section reports empirical studies on centre formation within the Commission, thus highlighting some key inconclusive results. The conclusion suggests ways to reconcile these divergent findings.

\section{CENTRE FORMATION AS ANALYTICAL CONCEPT}

Given that a new European executive centre is emerging, how can centre formation be recognised? As an analytical concept, the integration of a European executive centre may be analysed according to four analytical dimensions: independence, integration, co-optation and institutionalisation. The focus of this article is primarily on the second dimension - integration.

a. First, centre formation necessitates the rise of independent administrative resources and capacity. Envisaged already by Saint-Simon in 1814 (1964: 35-38), one necessary factor in building common political order is the establishment of common institutions, including a permanent congress independent of national governments serving the common interest. In a European context it necessitates the rise of separate institutions - organised according to principles of organisation that cross-cuts domestic government institutions - that are able to act relatively independent from member-state governments. Centre formation through institutional capacity building and institutional differentiation is seen as one key ingredient of state formation (Bartolini 2005). Centre formation above nation-state structures, however, is largely under-researched. If one focuses on system transformation in a European context, what matters is the extent to which a European executive centre is in practice autonomous from key components of an intergovernmental order, not whether its is autonomous in general. Moreover, the rise of executive centre may also involve the creation of relatively independent accountability re- lationships between the executive centre and a relatively independent European legislative chamber (e.g. the European Parliament (EP)), thus ultimately challenging an inherent intergovernmental accountability order (see Bovens et al., 2010).

b. Secondly, and the empirical focus of the present article, centre formation requires some degree of integration of government institutions. This entails both the integration of common administrative resources (for example the de facto integration of the Commission and EU agencies) as well as the internal integration of each institution, thus reinforcing intra-institutional administrative hierarchies. The emphasis in the below discussion is on the latter, that is internal integration of the Commission administration.

c. Third, centre formation entails that this independent and integrated order is also able to co-opt administrative sub-centres by stealth. In a European context this would entail that there is a process of integration of domestic agencies and relevant EU administrative structures. Secondly, this might also imply that EU institutions co-opt other international bureaucracies, thus developing common political order beyond the EU through the emergence of common global administrative architectures.

d. Fourth, centre formation would involve not only structural relationships among institutions but also the institutionalisation of shared values within and among these. Those common values may be important in defining common purpose and the social cement of a common order.

\section{RESULTS AND DISCUSSION: CENTRE FORMA- TION IN THE COMMISSION - INCONCLUSIVE RESULTS?}

Empirically it is often observed that executive centre formation does not result in integrated and coherent executive orders consisting of perfectly-integrated and monolithic institutions. Executive centres do not typically 'hang together', exhibiting coherence and predictability. Instead, different components of executive centres are observed to overlap, counteract, layer and sometimes be out of synch rather than being integrated, co-ordinated and 'ordered' (Orren and Skowronek 2004). Compound executive centres are typically characterised by the co-existence of multiple and co-evolving decision-making and accountability dynamics. Behavioural dynamics among actors are seen to co-exist but the mix tends to change over time as well as between different institutional contexts (Olsen 2010). As seen below, the Commission may be characterised as a compound executive centre by featuring a combination of two behavioural logics among its personnel.

Centre formation has been demonstrated within the Commission at several points throughout its history - notably under the Jean Monnet and Jaques Delors Presidencies. "At the end of Delors' ten-year tenure at the helm of the commission its potential for political leadership ... had been demonstrated conclusively" (Christiansen 2008: 63). Essentially, however, the power-base of these presidents and their policy initiatives were not safeguarded through bureaucratic 
capacity building within the Commission at the time. A relative downgrading of bureaucratic organisation was also observed throughout the Monnet Presidency decades earlier. Jean Monnet had the vision of great leadership from the top of the EU executive, with assistance of a small and flexible expert administration consisting of seconded national experts. Jean Monnet did not envision a permanent bureaucracy as inherent in Western democracies. By contrast, it was Walter Hallstein - Commission president 1958-67 - who designed the Commission into a bureaucratic organisation (Loth and Bitsch 2007: 58). According to this design, most of the powers in the Commission were left to the policy DGs and fairly little to the command centre of the College and the General Secretariat.

The Commission administration has more recently experienced substantial capacity building around the Commission President and the General Secretariat, supplementing an inherent DG supremacy. Contemporary presidentialisation in the Commission is perhaps mainly characterised by the building of administrative capacities around the Commission President, partly by reforming the General Secretariat into an administrative service centre at the disposal of the President. The General Secretariat has been considered the powerhouse of the Commission throughout the Commission history, largely due to the man who held the post as SecretaryGeneral from 1958 to 1987, Emile Noël (see Kassim 2006). By contrast, the increased presidentialisation of the Barroso I Commission is perhaps primarily associated with organisational capacity-building inside the Commission, making the General Secretariat a steering and co-ordinating centre for the President. It is also reported that the sheer style of the current Barroso II Presidency may become more 'presidential-like'. Notable examples of this is that the President increasingly 'attach his name to policy initiatives', a decline of collegiality inside the College of Commissioners, increased horizontal interference by the President in the portfolios of other Commissioners, a restructuring of the General Secretariat to make it more of a service centre for the President, and increased staff resources at the disposal of the Secretariat General (Kassim and Peterson 2011). In short, the Commission President has gained enhanced capacity to steer and coordinate 'the house'.

The presidentialisation of the Commission administration, however, only supplements the horizontal specialisation and 'siloisation' of the Commission sub-units (primarily the policy DGs (ministries)). The 'siloisation' of the services is increasingly echoed in the College where Commissioners have become less collegial and more portfolio oriented (Joana and Smith 2004; Kurpas et al., 2008). The nonportfolio dynamic observed in previous studies thus seem to become subsequently weakened over time in the College (Joana and Smith 2004). This is reflected in College meetings, in the relationship between the Commissioners and their DGs, and also the development of direct links between Commissioners and 'their' Community agencies (Groenleer 2009: 130).

Centre ambitions of the General Secretariat sometimes exceed centre capacities. The horizontal interlocking role of the General Secretariat tends to collide with the organisational structure of policy DGs. Centre formation in the Commission thus seems sometimes dashed by the horizontal specialisation of the DGs. 'Silo thinking' is organisationally vested within the Commission services. Concomitantly, studies suggest that contact patterns among officials within policy DGs are strongly driven by their portfolios (Trondal 2012). A recent study also confirms that even informal networks inside the Commission are guided by the horizontal specialisation of the services, and largely clustered within DGs (Suvarierol 2007: 118). Moreover, patterns of co-operation and conflict inside the Commission are largely associated with the formal organisational boundaries of the services. Trondal (2012) also report that this effect is largely sustained and strengthened by the more recent compulsory staff rotation system. Moreover, the vast majority of the data reported in Trondal (2012) reveals that Commission officials mainly direct their identities towards the DGs and only secondary towards the unit level and the Commission as a whole.

Trondal (2012) reports that centre formation inside the Commission is primarily observed in the Commission's General Secretariat and only marginally inside policy DGs. In short, centre formation inside the Commission does not seem to profoundly penetrate the services. Reflecting the Neo-Weberian model outlined by Ongario (2010), Trondal (2012) suggests that two behavioural logics tend to co-exist within the Commission administration, albeit embedded and layered within different organisational sub-units. As could be predicted, a portfolio logic seems to be overwhelmingly present within policy DGs. The portfolio logic is reported as a foundational dynamic at the heart of such DGs and it seems to be activated fairly independently of centre formation at the helm of the Commission. This observation echoes images of the Commission administration as fragmented with weak capacities for hierarchical steering, accompanying interservice 'turf wars' that are marginally compensated for by presidential control and administrative integration (Bellier 1997; European Commission 1999; Coombes 1970; Egeberg 1996; Page 1997; Spinelli 1966, Trondal et al., 2008). Previous studies has pictured the Commission as organisationally segmented (Hooghe 1997; Page 1997: 135) and with an alleged 'management deficit' (Levy 2006; Metcalfe 1992). Hussein and Peterson (2011), however, suggest that the inherent logic of portfolio is increasingly challenged by centre formation in the Commission General Secretariat.

These abovementioned findings hold both when comparing permanent and temporary Commission officials (Trondal et al., 2010), and when 'controlling for' recent managerial reforms inside the Commission. Recent administrative reforms of the Commission have been described as historic, profound in depth, and wide-ranging in scope (Barzelay and Jacobsen 2009; Bauer 2009; Schön-Quinlivan 2006). Yet, research suggests that the behavioural logics among Commission officials are not profoundly transformed by such reforms (Trondal 2012). By contrast, the two behavioural logics reported above among Commission officials seem to be mainly guided by the organisational specialisation of the Commission services and the accumulation of relevant organisational capacities at the bureaucratic centre of the Commission. Re-engineering a large Commission administration is not done overnight. Despite ambitious policies to modernise and reform the Commission during the last decade, some data suggests that the results are modest as regards transforming the behavioural logics of Commission officials. 


\section{CONCLUSIONS}

Reflecting a compound executive centre, the Commission administration features a particular combination of two generic logics: a logic of hierarchy and a logic of portfolio. These logics highlight competing understandings of bureaucratic organisation, administrative behaviour, and bureaucratic change. This research note article has suggested that centre formation inside the Commission is primarily observed in the Commission's General Secretariat and only marginally inside policy DGs. As such, seemingly competing observations might be reconciled because competing behavioural logics tend to co-exist within the Commission administration, albeit embedded and layered within different organisational sub-units.

Trondal (2012) and Hussein and Peterson (2011) document behavioural patterns among Commission officials that are compatible with centre formation inside the Commission. These observations, however, are primarily found among officials at the bureaucratic centre of the Commission within the General Secretariat. The inherent portfolio logic among officials in policy DGs seems only marginally affected by the presidential ambitions of Barroso as well as the increased administrative capacities of the General Secretariat. Reasons for this may be that centre formation inside the Commission is fairly recent and that Commission officials remain primarily guided by an unreconstructed Commission bureaucratic architecture. It might thus be too early to say if centre formation has become institutionalised or if it merely reflect management styles of both President Barosso and Secretary General Cathryn Day. What is also important is that contemporary centre formation in the Commission is contingent and profoundly affected by pre-existing organisational structures in the services - by the 'genetic soup' of pre-existing organisational structures within the Commission administration (Olsen 2010: 96). Centre formation by the General Secretariat seems partly dashed throughout policy DGs largely due to the inherent portfolio specialisation of the DGs.

\section{ACKNOWLEDGEMENT}

None declared.

\section{CONFLICT OF INTEREST}

None declared.

\section{REFERENCES}

Bartolini, S. (2005). Restructuring Europe. Oxford: Oxford University Press.

Barzelay, M. and Jacobsen, A.S. (2009). Theorizing Implementation of Public Management Policy Reforms: A case study of strategic planning and programming in the European Commission. Governance, 22(2), 319-334.

Bauer, M. W. (Ed.). (2009). Reforming the European Commission. London: Routledge.

Bellier, I. (1997). The Commission as an Actor: An Anthropologist's View. In: Wallace, E. and Young, A.R. (Eds.). Participation and PolicyMaking in the European Union. Oxford: Clarendon Press.

Biermann, F., and Siebenhuner, B. (Eds.). (2009). Managers of Global Change. Cambridge: The MIT Press.

Bovens, M., Curtin, D., and 't Hart, P. (Eds.). (2010). The Real World of EU Accountability. What Deficit? Oxford: Oxford University Press.
Christensen, T., and Lægreid, P. (Eds.). (2007). Transcending New Public Management. The Transformation of public sector reforms. Aldershot: Ashgate.

Christiansen, T. (2008). The Institutional Politics of the European Union. Proefschrift: University of Maastricht.

Coombes, D. (1970). Politics and Bureaucracy of the European Union. London: Georg Allen and Unwin.

Curtin, D., and Egeberg, M. (2008). Tradition and Innovation: Europe's Accumulated Executive Order. West European Politics (Special Issue), 31(4), 639-661.

Egeberg, M. (1996). Organization and nationality in the European Commission services. Public Administration, 74, 721-735.

Egeberg, M., and Trondal, J. (2009). Political Leadership and Bureaucratic Autonomy. Effects of Agencification. Governance, 22(4), 673-688.

European Commission (1999). Designing Tomorrow's Commission. Brussels.

Groenleer, M. (2009). The Autonomy of European Union Agencies. Proefschrift. University of Leiden.

Hooghe, L. (1997). A House with Differing Views: The European Commission and cohesion policy. In: Nugent, N. (Ed.), At the Heart of the Union. Houndmills: Macmillan.

Joana, J., and Smith, A. (2004). The politics of collegiality: the nonportfolio dimension. In: Smith, A. (Ed.), Politics and the European Commission. London: Routledge.

Kassim, H. (2006). The Secretariat General of the European Commission. In: Spence, D. (Ed.), The European Commission. London: John Harper Publishing.

Kassim, H. (2009). "Mission impossible", but mission accomplished: the Kinnock reforms and the European Commission. In: Bauer, M. W. (Ed.), Reforming the European Commission. London: Routledge.

Kassim, H., and Peterson, J. (2011). Political leadership in the European Commission. In: Kassim, H., Bauer, M. W., Dehousse, R., Hooghe, L., and Thompson, A. (Eds.), The European Commission of the $21^{\text {st }}$ Century: Administration of the Past or Future. Oxford: Oxford University Press (forthcoming).

Kassim, H., and Menon, A. (2004). European Integration since the 1990s: Member States and the European Commission. Paper presented at ARENA seminar, 11. February 2004, University of Oslo.

Keohane, R.O., Macedo, S., and Moravcsik, A. (2009). DemocracyEnhancing Multilateralism. International Organization, 63,1-31.

Kreppel, A. (2011). Looking "Up", "Down" and "Sideways": Understanding EU Institutions in context. West European Politics, 34(1), 167-179.

Kurpas, S., Grøn, C., and Kacsynski, P.M. (2008). The European Commission after Enlargement: Does more add up to less? Brussels: CEPS Special Report.

Levy, R.P. (2006). European Commission overload and the pathology of management reform: Garbage cans, rationality and risk aversion. Public Administration, 84(2), 423-439.

Loth, W., and Bitsch, M.-T. (2007). The Hallstein Commission 1958-67. In: Dumoulin, M. (Ed.), The European Commission, 1958-72. History and memories. Brussels: European Commission.

Metcalfe, L. (1992). After 1992: Can the Commission Manage Europe?. Australian Journal of Public Administration, 51(1), 117-129.

Olsen, J.P. (2010). Governing Through Institutional Building. Oxford: Oxford University Press.

Ongario, E. (2010). Administrative reforms in the European Commission: towards New Public Management, 'old' bureaucracy, or NeoWeberianism?. Unpublished paper.

Orren, K., and Skowronek, S. (2004). The Search for American Political Development. Cambridge: Cambridge University Press.

Page, E. C. (1997). People Who Runs Europe. Oxford: Clarendon Press.

Peterson, J. (2011). Navigating the European Commission. In: Kassim, H., Peterson, J., Bauer, M. W., Dehousse, R., Hooghe, L., and Thompson, A. (Eds.), The European Commission of the $21^{\text {st }}$ Century: Administration of the Past or Future. Oxford: Oxford University Press (forthcoming).

Pogunthe, T., and Webb, P. (Eds.). (2005). The Presidentialisation of Politics. Oxford: Oxford University Press.

Rokkan, S. (1999). State Formation, Nation-Building and Mass Politics in Europe. Oxford: Oxford University Press.

Saint-Simon, H. (1964). Social organization, the science of man and other writings. New York: Harper Torchbooks.

Schön-Quinlivan, E. (2006). Administrative reform in the European Commission: From rhetoric to re-legitimation. EU-Concent working paper, No. 17. 
Spinelli, A. (1966). The Eurocrats. Conflict and Crisis in the European Community. Baltimore: The Johns Hopkins Press.

Suvarierol, S. (2007). Beyond the Myth of Nationality. A Study of the Networks of European Commission Officials. Proefschrift, Utrecht School of Governance.

Trondal, J. (2010). An Emergent European Executive Order. Oxford: Oxford University Press.
Trondal, J. (2012). On Bureaucratic Centre Formation in Government Institutions. Lessons from the European Commission. International Review of Administrative Sciences (forthcoming).

Trondal, J., Marcussen, M., Larsson, T., and Veggeland, F. (2010). Unpacking International Organisations. The dynamics of compound bureaucracies. Manchester: Manchester University Press.

Trondal, J., Van den Berg, C., and Suvarierol, S. (2008). The compound machinery of government. The case of seconded officials in the european commission. Governance, 21(2), 253-274.

(c) Jarle Trondal; Licensee Bentham Open.

This is an open access article licensed under the terms of the Creative Commons Attribution Non-Commercial License (http://creativecommons.org/licenses/by-nc/3.0/) which permits unrestricted, non-commercial use, distribution and reproduction in any medium, provided the work is properly cited. 